\title{
Microplastic in Cymodocea rotundata Seagrass Blades
}

\author{
Syeiqido Sora Datu ${ }^{1}$, Supriadi $^{2}$, Akbar Tahir ${ }^{2 *}$
}

\author{
${ }^{1}$ Integrated Coastal Resources Management Postgraduate Program, Faculty of Marine Science and Fisheries, \\ Universitas Hasanuddin, Makassar 90245 \\ ${ }^{2}$ Department of Marine Science, Faculty of Marine Science and Fisheries, Universitas Hasanuddin, Makassar 90245 \\ *Corresponding author: akbar_tahir@mar-sci.unhas.ac.id
}

\begin{abstract}
Microplastic known to contaminate all ecosystem in the ocean, including seagrass bed. Leaf is one of the important parts of seagrass. The presence of ephibiont that attached to the surface of the seagrass leaves, causes the leaves' surface texture becoming rough, enabling microplastic entrapped in it. To assess the extent of microplastic accumulation, seagrass samples were collected from Barrang Caddi Island. Of the 15 seagrass blades harvestedin Barrang Caddi Island, there are 23 total items of microplastic observed, comprises $91 \%$ of microfibers and $9 \%$ were microfragments.
\end{abstract}

Keywords - Seagrass, blades, ephibiont, microplastic.

\section{INTRODUCTION}

Plastic waste pollution in aquatic ecosystem is now a global concern (Andrandy,2011; UNEP, 2015). 60-80\% of total marine waste is estimated to consist of plastic waste, there is no consensus about the total amount of plastic in the ocean or how much is added / stored annually, although the model predicts that around 10 million tons of plastic are added each year, with the total amount accumulated in 2025 estimated at least 155 million tons(Iñiguez et al., 2016). Jambeck et al, (2015) described the distribution of plastic waste in several countries, one of which is Indonesia. In that survey, Indonesia is estimated to produce $0.48-0.29$ million tons/year of plastic waste. The large amount of plastic that collected and accumulated in marine waters is a problem that might disturb the stability of the ecosystem in sea waters(Gray, 2017). Although plastic is persistent, along with the time it can be degraded into smaller particles by waves, sunlight (photodegradation), oxidation, and mechanical abrasion (UNEP, 2015). Plastic fragment which degraded, often called microplastic (herein after referred to as MPs), have particle sizes of less than 5mm (Tankovic, 2015). Degraded plastics are widely distributed in ocean waters. Size and density affect the presence of this MPs in the aquatic environment. Plastics with high density, that exceeds of seawater $\left(1.02 \mathrm{~g} \mathrm{~cm}^{-3}\right)$ will sink and accumulate in the sediment (Woodall et al., 2015), while low-density particles tend to float on the sea surface (Suaria and Aliani, 2014). With a small size will ease for MPs to be carried by currents and waves that are easily trapped in the ecosystem in the sea, one of which is the seagrass
ecosystem.Recent findings on MPs contamination on different seagrass percent coverage was conducted by Tahir et al. (2019) clearly shown the potential of MPs transfer pathways to the food chain. Research conducted by Gross (2018) found the presence of MPs on the leaves ofThalassia testudinum. Potential mechanisms to explain how plastic can be found in seagrasses, the first is that MPs suspended in the water column are trapped in epiphytes found in seagrass leaves.Second, MPs may stick to seagrass blades via adhesive biofilms (Rummel, 2017). Each type of seagrass has a different morphological form, ranging from cylindrical leaves on Syringodium, to the ribbon leaves in Enhalus, Cymodocea, Posidonia, Thalassia, and Zostera. These various forms of morphology have different effects on the epiphytic community in seagrass beds (Reynold, 2018). This is related to the difference in surface area provided by each of the seagrass plants for epiphytic attachment. Seagrass with a larger surface area allows more epiphytes to stick, which in turn allows more MPs trapped as well. The presence of MPs in seagrasses will certainly have an impact on seagrasses themselves and the organisms that make seagrasses as their food stuff. Seagrass is well known as one of the primary producers in the seawhich plays an important role in the food chain network in marine waters. The presence of MPs in seagrass beds has a potential to enter the body of herbivore organisms, especially those eating seagrass leaves and organisms that eat epiphytes on the surface of the seagrass leaves. In seagrass, plastic can act as inhibitor in the process of photosynthesis so that it can cause disruption of seagrass 
growth itself (Mandasari, 2014). Consideringthe dangers and impacts that can be generated, it is important to see the extent to which MPs can enter and reside in seagrasses ecosystem. This study aims to look at the presence of MPsin medium-sized seagrassplant such as Cymodocea rotundata

\section{RESEARCH METHOD}

\subsection{Field collections}

Sample of Cymodocea rotundata were collected on August $3^{\text {th }} 2019$, at Barrang Caddi Island, nearby Makassar City. A total 15 seagrass blade were handharvestedalong the seagrass beds.Samples were put into sample bag and transported toLaboratory of Marine Ecotoxicology, Hasanuddin University for later laboratory analysis, including sample preparation, microscope observation and Fourier transformed infrared spectroscopy (FTIR).

\subsection{Measurement of Area and Percentage of Epiphytic} Cover in Seagrass Leaves.

Prior to the observation of MPs in seagrass, the length and width of the seagrass leaves were measured using caliper. To calculate the percentage of epiphytic cover on a seagrass blade, each seagrass leaf was measured by leaf area covered by epiphytes.

\subsection{Microplastic Analysis}

To prevent any contamination of the samples, the microscope, glass surfaces and all the tools for MPs analysis, were cleaned with tissue paper and sterile distilled waterbetween each imaging session on each sample analysis. Blades of Cymodocea rotundata were examined, photographed and analyzed using a Euromex stereo microscope SB 1903. The presence of MPs on the blades was recorded along with the color and shapes as either micro-fibers or micro-fragments.To find out the types of polymers in observed MPs, an analysis was conducted using Fourier Transform Infrared Spectrophotometer (FTIR).

\section{RESULTS AND DISCUSSION}

\subsection{Microplastic Found in Cymodocea rotundata}

Of the 15 seagrass blades collected, 13 blades $(87 \%)$ were found containing microplastic (MPs), 2 blades (13\%) did not appear to contain MPs. The number of MPss found in all blades are 23 items. Where 4 leaf blades with epiphytic percentage $<25 \%$ found ( 2 MPs). 7 seagrass leaf blades with $25-50 \%$ epiphytes, found (13 MPs). 3 seagrass leaf blades with 50-70\% epiphytes, found (6 MPs) and 1 seagrass leaf blade with epiphytes $>70 \%$, present $(2 \mathrm{MsP})$
(Fig. 1). For MPs abundance on the leaves of Cymodocea rotundatawere ranged from $0.271-1.139 \mathrm{MP} / \mathrm{cm}^{2}$.

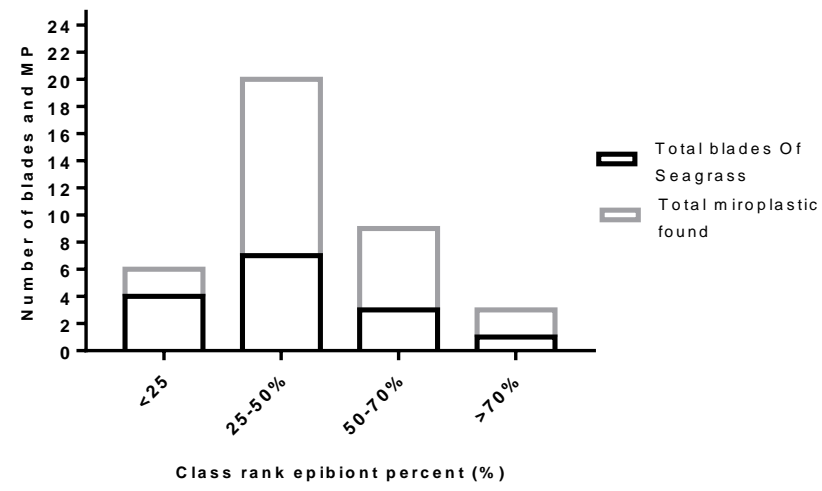

Fig.1: Abundance of MPs observed in seagrass blade of Cymodocea rotundata.

Other research also found the presence of MPs reigns on epiphytes attached to different types of seagrass leaves, Thalassia hemprichii, on 15 seagrass blades, a total 71 MPs were found consisting of 12 microbeads and 59 in the form of microfilaments (Goss, 2018). In addition, 199 MPs on Enhalus acoroides leaves and 126 MPs on Thalassia hemprichii leaves have also been found (Sawalman, 2018). And there are several mechanisms that can explain how MPs can be trapped in seagrass leaves, first through epiphytic species attached to the surface of the seagrass leaves which may be able to capture MPs suspended in the water column, seagrass surfaces overgrown with epiphytes will be rough so that MPs can be trapped in them, secondly MPs can stick to adhesive biofilms (Gross, 2018). In addition, the large number of epiphytes found on the surface of seagrass blades can also allow more MPs to be trapped. The number of epiphytes on the surface of seagrass blade depend on the size of the blades, where total abundance of Enhalus acoroides epiphytic meiofauna composition, comprises of 145 individuals from 10 classes (leaf tips: 114 individuals, leaf base: 31 individuals), also in Thalassia hemprichiicomprises of 64 individuals from 7 classes (leaf tips: 35 individuals, leaf base: 29 individuals), and Cymodocea rotundata, consist of 42 individuals from 7 classes (leaf tips: 20 individuals, leaf base: 22 individuals) (Lestari,2010). Statistical analysis using linear regression has revealed no significant difference in the abundance of epiphytes and the amount of MPs observed ( $P$ value $=$ 0.566). However, by comparing the results of research from previous studies (Gross, 2018) and (Sawalman, 2018), it can be seen that larger-sized seagrasses such as Enhalusacoroides and medium-sized Thalassiahemprichii have a greater amount of MPs abundance compared to small-sized seagrass Cymodocearotundata. 
3.2 Shape and color of microplastic found

Overall, the MPs forms found from 15 seagrass blades (Fig. 2) there are $91 \%$ were microfibers and $9 \%$ were micro-fragments. Of the 15 seagrass blades comprehensively examined. Furthermore, a total of 21 micro-fibers were found ranging from 0 to 3 item/blade, while for the micro-fragments were ranging from 0 - 1 per single blade.Previous research has also found MPs, and the microfiber is the most dominant found in seagrass blades (Sawalman, 2018; Goss, 2018).Other studies have also shown the presence of MPs fibers and fragments in the seaweed epiphyte Fucus vesiculosus (Gutow, 2016). The large number of microfibers found may have been caused by the sampling location in the fishing activity area and the fishing area parked the boats, where most of the fishing gear used by fishermen came from ropes or plastic sacks that had degraded.In line with previous studies that this type of fiber MPs is widely used in the manufacture of clothing, rigging, various forms of fishing gears such as fishing rods and fishing nets (Nor and Obbard, 2014).

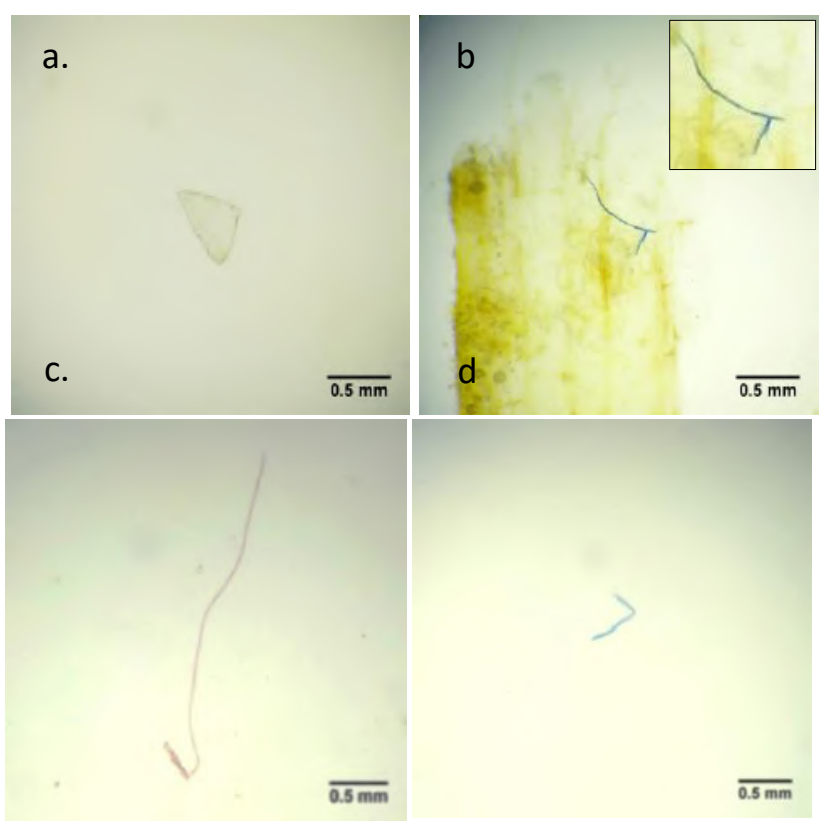

Fig.2: Microplastic (MP) found in seagrass blades Cymodocea rotundata; (a.) Fragment, (b-d) Line

From a total of 15 samples of seagrass leaves, MPsfound in 3 colors predominated by blue ( $82 \%)$, clear and red $(9 \%)$ each. For seagrass leaf size, from 23 MPs obtained, the size ranges from $1.053 \mathrm{~mm}-4.081 \mathrm{~mm}$. With the small size of the MPs that is in the seagrass blades can be incorporated into the body of the herbivore through the process of the food chain. One example of a case involving the entry of MPs when consuming seaweed contaminated with MPs is the laboratory experiments conducted by Gutow(2016),found seaweed Fucus vesiculosus which was contaminated with MPs, given to be consumed by Littorinalittorea resulted that the MPswere found in the stomach and in the gut. The impact of the presence of MPs that enter and digested in organisms has been noted in research by Nobre et al.(2015) where toxins carried by MPs can cause anomalies during embryonic development of invertebrates urchin species Lytechinus variegatus. The impact of MPs is not only on organisms that eat seagrass leaves that are contaminated with MPs, but as one of the primary producers the presence of MPs can also threaten the growth of the seagrass itself. According to Yokota (2018), one of the primary producers in the algae is Cyanobacteria, showing its interaction with MPs can change the process of photosynthesis of algae, growth, gene expression, colony size and morphology. The existence of these changes may be caused by adhesion and/ortransfer of pollutants absorbed from MPs.

\subsection{Fourier Transform Infrared Spectrophotometer (FTIR)}

Analysis.

FTIR analysis was carried out to determine the polymers ofMPs items found on Cymodocea rotundata were resulted as polystyrene (PS) (Figure 3) and Nylon (Figure 4) polymers.

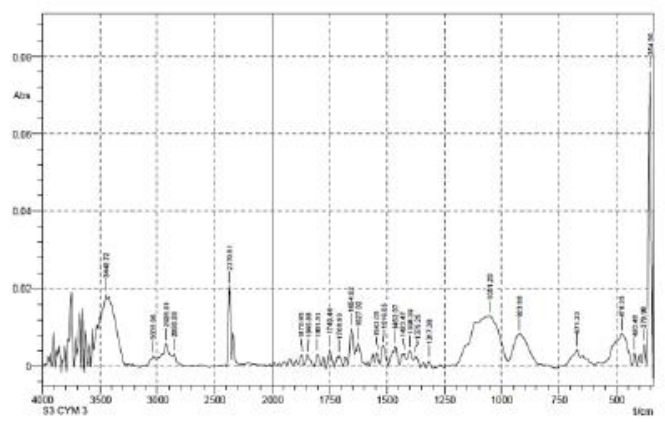

Fig.4: Microplastic FTIR spectrographshowing compatibility with Polystyrene polymers.

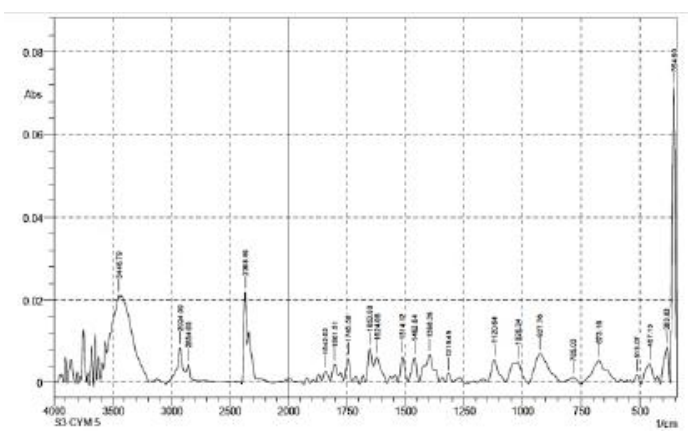

Fig.5: Microplastic FTIR spectrograph showing compatibility with Nylon polymers.

Techniques in comparing the size, shape and type of polymer content may be useful in providing insight to determine the sources of MPs in the ocean. Generally the types of polymers found in the sea consisted by 
polyethylene, polystyrene, polypropylene (Browne, 2011). Of the microplastic FTIR analysis the polystyrene polymers that are widely used to make food containers and plastic bags, and the nylon polymers are used to make fishing rope, were identified in the present studies and confirmed their wide distribution in the marine environment.

\section{CONCLUSION}

Microplastic has been found in seagrass blades of Cymodocea rotundata, with the dominant form being microfiber. The presence of MPs in seagrass is thought to be trapped by epiphytes on the surface of seagrass leaves, but it remains uncertain on how long MPs can reside in seagrass and how much the contribution of seagrass as a pathway for MPs entry into organisms, especially herbivores.

\section{REFERENCES}

[1] Andrady, A.L. 2011. Microplastic in The Marine Environment. Mar. Pollut. Bull. 62 (8): 1596-1605. https://doi.org/10.1016/j.marpolbul.2011.05.030.

[2] Browne, M.A., Crump P, Niven SJ, Teuten EL, Tonkin A. (2011) Accumulations of microplastic on shorelines worldwide: sources and sinks. Environ. Sci. Technol. 45: 9175-9179. https://doi.org/10.1021/es201811s.

[3] Gray. D. A, John E.W. 2017. Size and Shape Dependent Effect of Microplastic Particles on Adult Dagger-blade Grass Shrimp, Palaemonetes Pugio. Department of Biology, University of North Carolina at Greensboro, Greensboro, North Carolina, USA. https://doi.org/10.1002/etc.3881

[4] Gross, H., Jaskiel, J., Rotjan, R. 2018. Thalassia testudinum as a potential vector for incorporating microplastics into benthic marine food webs. Mar. Pollut. Bull. 135: 1085-1089. https://doi.org/10.1016/j.marpolbul.2018.08.024.

[5] Tahir, A., Samawi, F.M., Sari, K., Hidayat, R., Nimzet, R., Wicaksono, E.A., Asrul, L., Werorilangi, S. 2019. Studies on microplastic contamination in Seagrass beds at Spermonde Archipelago of Makassar Strait, Indonesia. J. Phys.: Conf. Ser. 1341022008.

[6] Gutow, L., Eckerlebe, A., Giménez, L., Saborowski, R., 2016. Experimental evaluation of seaweeds as a vector for microplastics into marine food webs. Environ. Sci. Technol. https://doi.org/10.1021/acs.est.5b02431.

[7] Nobre, C.R., Santana, M.F.M., Maluf, A., Cortez, F.S., Cesar, A., Pereira, C.D.S., Turra, A., 2015. Assessment of microplastic toxicity to embryonic development of the sea urchin Lytechinus variegatus (Echinodermata: Echinoidea). Marine Pollution Bulletin. 92 (99-104). https://doi.org/10.1016/j.marpolbul.2014.12.050.

[8] Iñiguez, M.E., Conesa, J.A., Fullana, A., 2016. Marine debris occurrence and treatment: a review. Renew.
64(2016)394-

402https://doi.org/10.1016/j.rser.2016.06.031

[9] Jambeck, J.R., Andrady, A., Geyer, R., Narayan, R., Perryman, M., Siegler, T., Wicox, C., Lavender Law, K., 2015. Plastic waste inputs from land into the ocean. Science. $\quad 347(6223)$ : 768-77. https://doi.org/10.1126/science.1260352

[10] Lestari, Ratna, M. 2010. Abundance and composition of meiofauna epiphytes on Enhalus acoroides, Thalassiahemprichii and Cymodocea rotundataat Bama Beach, Baluran National Park, East Java. Undergraduate Thesis of Biology, RSBi 593 (in Bahasa Indonesia).

[11] Mandasari. 2014Relations of seagrass condition and marine debris in Barrang Lompo Island. Undergraduate Thesis. Faculty of Marine Science and Fisheries, Universitas Hasanuddin. 57p (in Bahasa Indonesia).

[12] Nor, N.H. Mohamed, Obbard, J.P., 2014. Microplastics in Singapore's coastal mangrove ecosystems. Mar. Pollut. Bull. 79:278-283. http://doi.org/10.1016/j.marpolbul.2013.11.025.

[13] Reynolds. P.L. 2018. Seagrass and Seagrass Beds. Ocean.

[14] Rummel, C.D., Jahnke, A., Gorokhova, E., Kühnel, D., Schmitt-Jansen, M., 2017. Impacts of biofilm formation on the fate and potential effects of microplastic in the aquatic environment. Environ. Sci. Technol. http://doi.org/10.1021/acs.estlett.7b00164.

[15] Sawalman. R. 2018. Microplastic abundance in sea urchin (Diadema sitosum) in seagrass beds area at Barrang Lompo Island of Makassar City. Undegraduate Thesis. Faculty of Marine Science and Fisheries. Universitas Hasanuddin. 53p. (in Bahasa Indonesia).

[16] Suaria, G Aliani,S. 2014. Floating debris in the Mediterranean Sea. Marine Pollution Bulletin. 86:494504. http://doi.org/10.1016/j.marpolbul.2014.06.025.

[17] Tankovic, M.S. Perusco, V.S., J. Godrijan, D., M.P fannkuchen. 2015. Marine plastic debris in the north eastern Adriatic. Micro: Book of abstracts.

[18] UNEP. 2015. Biodegradable Plastics and Marine Litter. Misconceptions, Concerns and Impact on Marine Environments.

[19] UNEP. 2015. Plastic in Cosmetics are Polluting the Environment through Our Personal Care.

[20] Woodall, L.C., Gwinnett, C., Packer, M., Thompson, R.C., Robinson, L.F., Paterson, G.L., 2015. Using a forensic science approach to minimize environmental contamination and to identify microfibers in marine sediments. Mar. Pollut. Bull. 95 (1) : 40 - 46. http://doi.org/10.1016/j.marpolbul.2015.04.044.

[21] Yokota, K., Waterfield, H., Hastings, C., Davidson, E., Kwietniewski, E., Wells, B., 2017. Finding the missing piece of the aquatic plastic pollution puzzle: interaction between primary producers and microplastics. Limnol. Oceanograf. 2: 91-104. http://doi.org/10.1002/lol2.10040. 